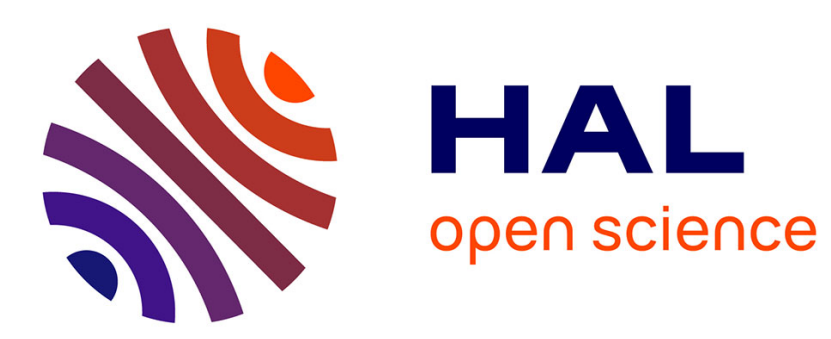

\title{
Life Cycle Assessment Practices: Benchmarking Selected European Automobile Manufacturers \\ Jean-Jacques Chanaron
}

\section{To cite this version:}

Jean-Jacques Chanaron. Life Cycle Assessment Practices: Benchmarking Selected European Automobile Manufacturers. International Journal of Product Lifecycle Management, 2007, 2 (3), pp. 290-311. 10.1504/IJPLM.2007.016293 . halshs-00205034

\section{HAL Id: halshs-00205034 https://shs.hal.science/halshs-00205034}

Submitted on 6 Apr 2009

HAL is a multi-disciplinary open access archive for the deposit and dissemination of scientific research documents, whether they are published or not. The documents may come from teaching and research institutions in France or abroad, or from public or private research centers.
L'archive ouverte pluridisciplinaire HAL, est destinée au dépôt et à la diffusion de documents scientifiques de niveau recherche, publiés ou non, émanant des établissements d'enseignement et de recherche français ou étrangers, des laboratoires publics ou privés. 


\title{
Life Cycle Assessment Practices: Benchmarking Selected European Automobile Manufacturers
}

\author{
Jean-Jacques CHANARON \\ Research Director GATE-CNRS and Professor Grenoble Ecole de Management (France) \\ e-mail: jean-jacques.chanaron@wanadoo.fr \\ Address: BP 12738003 GRENOBLE CEDEX 01
}

\begin{abstract}
With the rise of environmental concerns in the general public, re-appropriated by influential politicians, life cycle assessment (LCA) has become a widely used set of tools for the management of all impacts on environment by industrial products. LCA is carried out at the very early stages of product research, development and design. This is particularly true in the automobile industry where vehicle manufacturers (OEMs) are launching several new or revamped models each year. The automobile industry is therefore a very emblematic sector for best practices of LCA.
\end{abstract}

The paper is based on available literature and interviews with top LCA professionals in Germany-based OEMs.

\section{Key words}

Life cycle assessment, automobile, best practices

\section{Biographical note}

Professor J.J. Chanaron is currently Research Director within the French National Centre for Scientific Research (CNRS), Professor and Scientific Director at the Grenoble Ecole de Management where he is currently Director of the Doctoral School.

Jean-Jacques has published extensively via books, articles in refereed journals and conference papers in Industrial Economics, Economics of Innovation and Technology Management since 1973 when he received his $\mathrm{PhD}$ at the University of Grenoble. He also holds a HDR in Economics since 1994. He is Associated Professor and Researcher with Henley Management College, Manchester University and Newcastle University in the UK as well as Tongji University in Shanghai, China. He is a well-recognized expert in the automotive industry. He is consultant to International Organizations (EU, OECD, ILO, UNIDO), professional organizations (CCFA, FIEV, JAMA, CLEPA), OEMs (PSA, Renault, Toyota, Nissan, DaimlerChrysler, VW, Ford, Volvo) and numerous component manufacturers. He is a member of the French Society of Automotive Engineers (SIA) and the GERPISA International Network of Researchers on the Auto Industry. He is the co-editor of the International Journal of Automobile Technology and Management. In April 2004, he has been granted the IAMOT award for research excellence in Technology and Innovation Management. 


\section{Introduction}

In recent years, life cycle assessment (LCA) has become a widely accepted and disseminated management tool in most large global corporations. This article is about benchmarking current if not best practices in LCA within a sample of European automobile manufacturers (OEMs), namely DaimlerChrysler, Ford and Volkswagen. In some occasions, references are be made to experiences by some of their subsidiaries (Jaguar and Volvo for Ford Group) and leading first tier suppliers.

The study has been carried out in 2004 and is based on an extensive web-based literature review $^{1}$ and a limited number of open interviews with LCA professionals at high level within each company as well as academic specialists and general experts of LCA. The interviews were structured on a pre-defined set of questions derived from the key issues identified in the existing literature. The article is not a scientific paper per se but is presenting a synthesis and an analysis of the literature and interviews. The survey has been deliberately limited to European corporations.

\section{Literature Background: Mapping the Context}

\subsection{Definitions}

It is important to define precisely what life cycle assessment is since product and process life cycle has been considered as one of the key targets for several managerial disciplines and functions, such as general management (life cycle management), evaluation and control (LCA), design, as well as covers different functions.

Life Cycle Assessment is an analytical tool to systematically evaluate the environmental consequences of a product or activity holistically, across its entire life. LCA provides an adequate instrument for environmental decision support. Most companies have adopted the International Organization of Standards (ISO) Life Cycle Assessment guidelines defined in 14040 series documents published in 2002. Typically, energy and raw material requirements, atmospheric emissions, waterborne emissions, solid wastes, and other releases are mapped and inventoried over the entire life cycle of a product, package, process, material, or activity as shown in Figure 1. The impacts associated with these flows are evaluated. LCA can be conducted on product systems of varying complexity from milk and juice packaging to automotive transmission parts to larger more complex systems such as total vehicle and residential homes.

\footnotetext{
${ }^{1}$ All interesting articles and books have been included in the reference list even when not explicitly quoted in the text itself.
} 
Figure 1. General Product Life Cycle

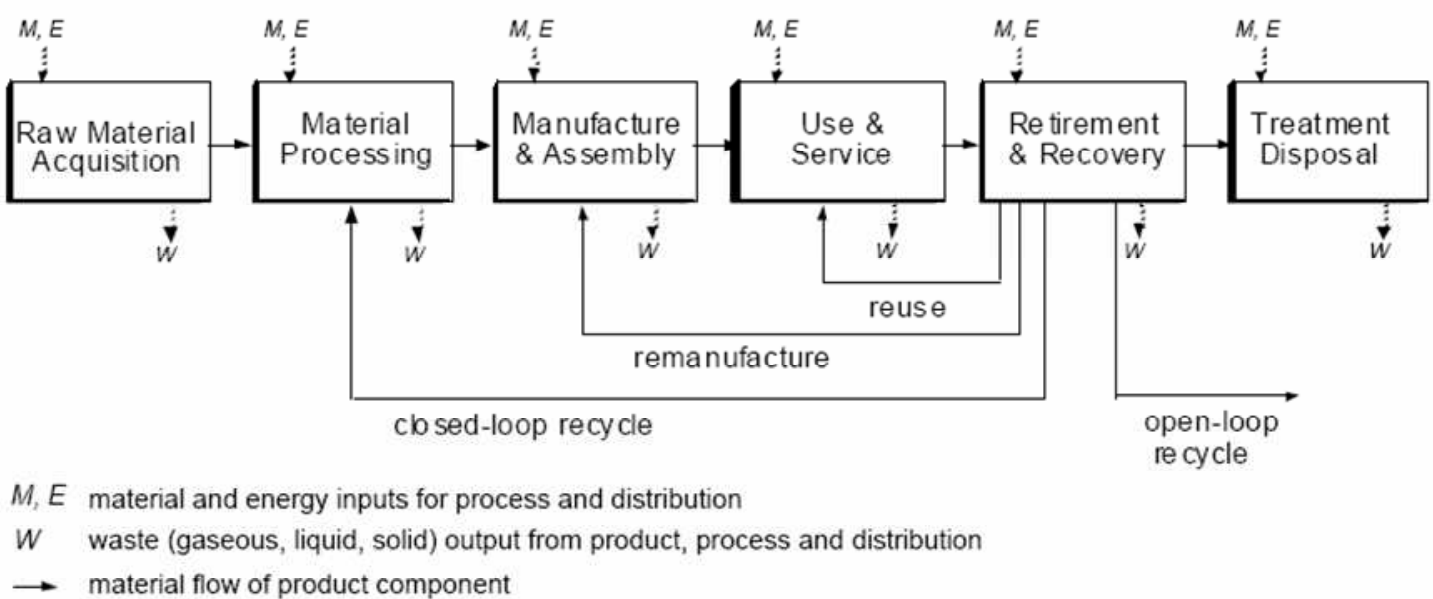

Source: ISO.

Life Cycle Management is an analytical tool for managing the total life cycle of processes, products and services towards more sustainable consumption and production patterns. LCM integrates economic, social and environmental aspects into an institutional context and is applicable for organisations demanding a system-oriented platform for implementation of a preventive and sustainability driven management approach.

Life Cycle Design is a framework (figure 2) for integrating environmental considerations into product development by considering all stages of a product's life cycle, from raw materials acquisition through manufacturing and use to final disposal of wastes. Activities include identifying system requirements, selecting strategies for meeting these requirements, and evaluating tradeoffs among system alternatives. Successful environmental integration often must be achieved within the context of shortening time to market cycles, more stringent regulations, and global competitiveness. The objective of life cycle design is to enhance environmental performance across the life cycle while also optimizing functional performance, cost, and regulatory/policy requirements that influence the product system. Design analysis of these product systems highlights opportunities for improvement.

Figure 2. Product Life Cycle System

Material Production

Manufacturing

Use

End-of-Life Management

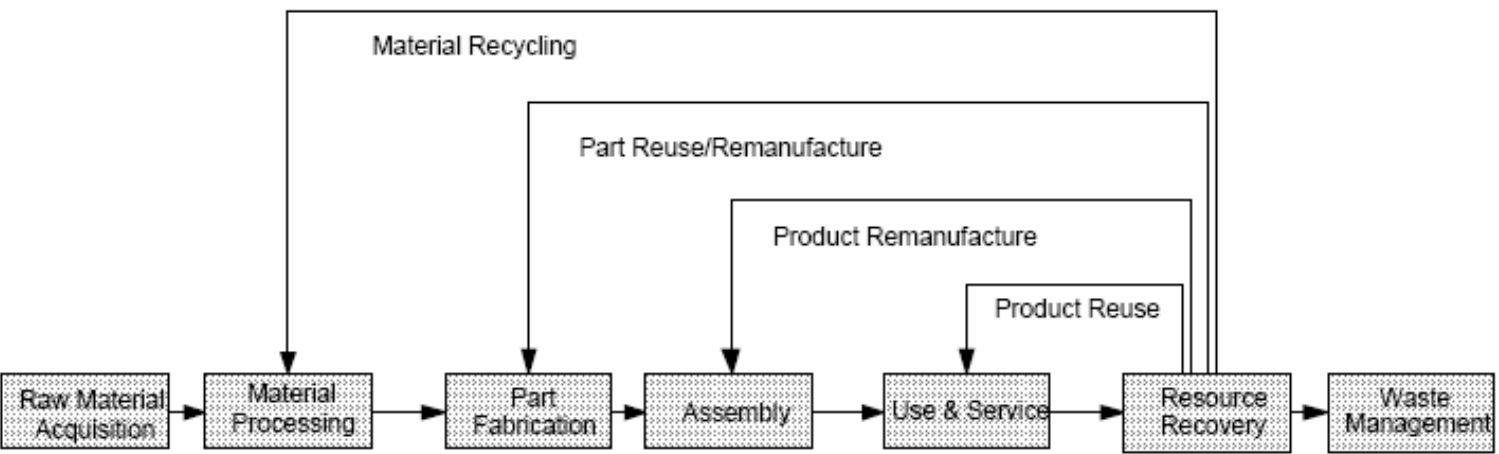

Source: Spitzley, Keoleian, (1999).

Life Cycle Costing (LCC) is a tool (figure 3) for evaluating all monetary costs associated with a system from acquisition, operation, maintenance, service and retirement. LCC 
addresses liabilities and hidden/less-tangible costs as well as externalities not accounted for in the current market system. As pointed out by Rebitzer and Hunkeler (2003), LCC in a part, obviously essential, of the overall assessment exercise.

Figure 3. Life Cycle Costing

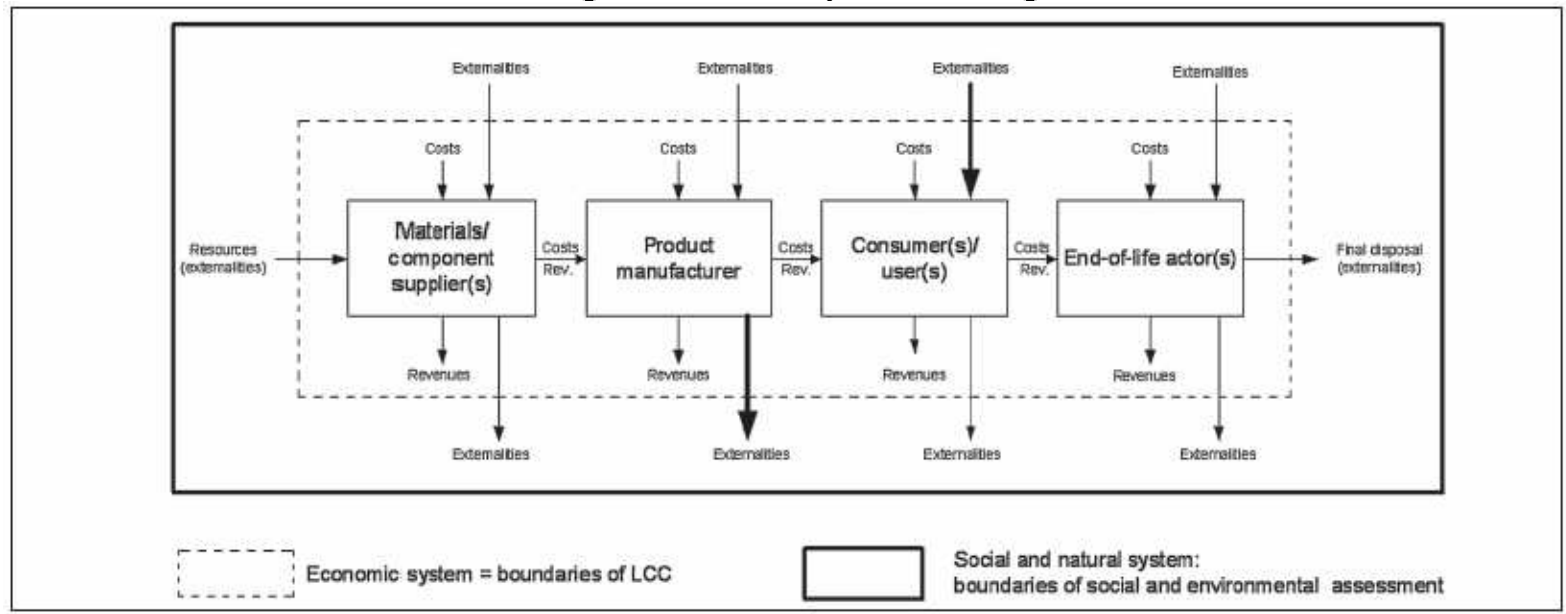

Sources: Rebitzer and Hunkeler (2003).

For future technologies, still in development, the Centre for Transportation Studies of the University of California at Davis, within the Fuel Cell Vehicle Modelling Program (FCVMP), open since 1998, has developed its own new model (figure 4), so-called Fuel Upstream Energy and Emissions Model (FUEEM) with the aim of minimizing the subjectivity and uncertainty of input data:

Figure 4. Future Technologies LCC

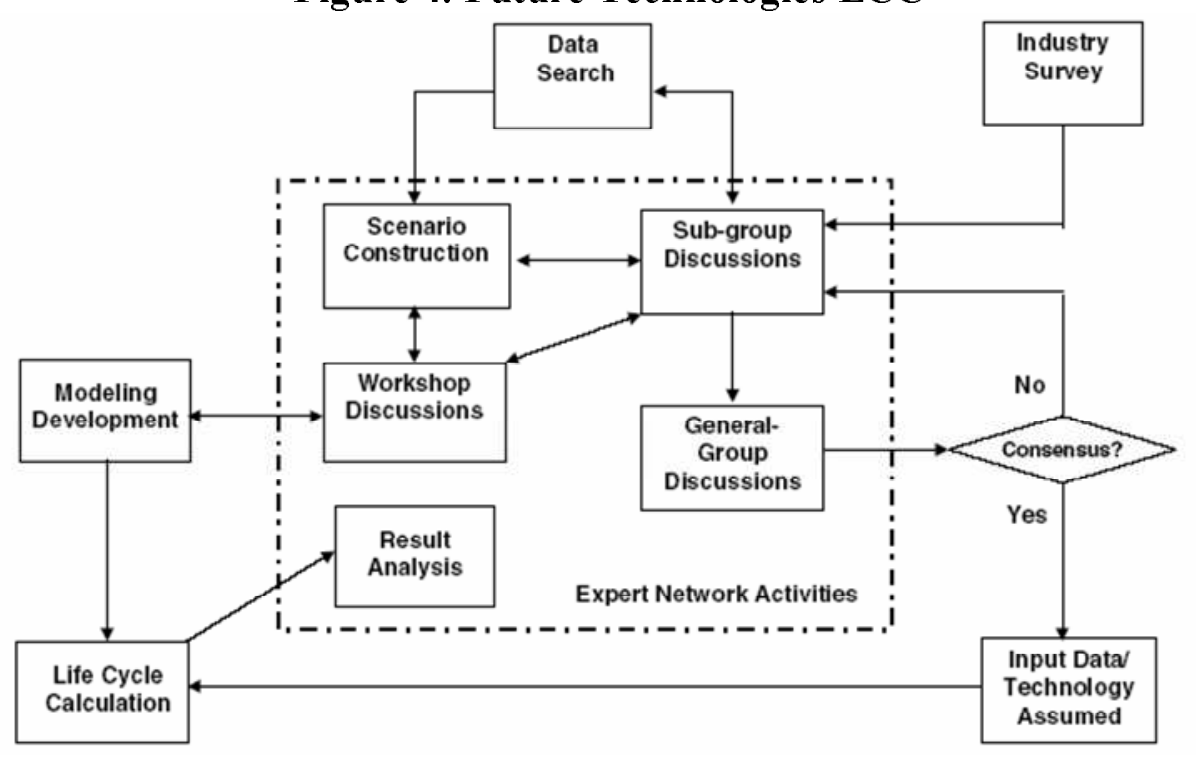

According to Contadini, Moore \& Mokhtarian (2002), expert network activity is supposed to produce better information than individual opinion and any foresight analysis should be conducted using intensively the Delphi procedure. In developing a LCA of bio-ethanol, Riley \& Sheehan, J., (2000), from the National Renewable Energy Laboratory, within the U.S. Department of Energy, emphasized the key role of all stakeholders in the LCA process (figure $5)$. 
Figure 5. Stakeholders' Approach

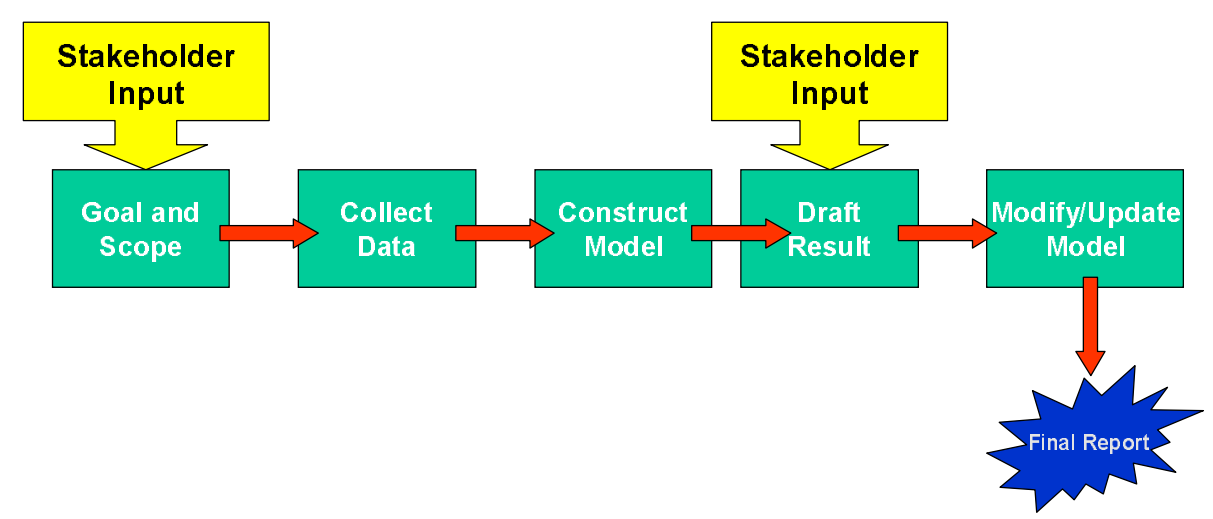

Source: Riley \& Sheehan, J., (2000).

\subsection{LCA software}

Obviously, there is a lot of software available on the market place. In 2000, IVL conducted a survey on 24 systems on behalf of the Swedish Industrial Research Institutes. In 2003, the most disseminated LCA software were the following:

- Boustead Consulting Database and Software

- ECO-it: Eco-Indicator Tool for environmentally friendly design - PRé Consultants

- EcoPro - sinum Corporate Environmental Management

- EDIP - Environmental design of industrial products - Danish EPA

- EIOLCA - Economic Input-Output LCA at Carnegie Mellon University

- GaBi 3 - (Ganzheitliche Bilanzierung) - University of Stuttgart (IKP)/PE Product Engineering

- IDEMAT - Delft University Clean Technology Institute Interduct Environmental Product Development

- KCL-ECO 3.0 - KCL LCA software

- LCAiT - CIT EkoLogik (Chalmers Industriteknik)

- LCNetBase - Life cycle assessment using traceable US data - Sylvatica

- SimaPro 5.0 for Windows - PRé Consultants

- SPOLD - Society for the Promotion of Life-cycle Assessment Development

- TEAM(TM) (Tools for Environmental Analysis and Management) - Ecobalance, Inc.

- Umberto - An advanced software tool for Life Cycle Assessment - Institut für Umweltinformatik

\subsection{Users of LCA in the automotive industry}

According to the Life Cycle Initiative launched in 2002 by the United Nations Environment Program (UNEP) and the Society of Environmental Toxicology and Chemistry (SETAC), the life cycle assessment approach is used by the following corporations (Table 1): 
Table 1. Examples of LCA Users

\section{Examples of companies using Life Cycle Approaches*}

Automotive Industrv: BMW, Daimler-Chrysler, Delphi, Dow Automotive, Fiat, Ford Motor Company, General Motors, Honda, Lear, PSA Peugeot Citroën, Toyota Motor Co., Volkswagen, Volvo

Packaging Industrv: Assidomän, Elopak, International Paper, Korsnäs, MeadWestvaco, Potlatch, SIG Combibloc, StoraEnso, TetraPak, Weyerhaeuser

Chemicals and Consumer Products Industry: 3M, BASF, Bayer, Black \& Decker, Bristol-Myers Squibb, British Petroleum, CIBA, Dow Chemicals, DuPont, Henkel, Johnson \& Johnson, Nordisk, Novo, Procter \& Gamble, SC Johnson, Unilever
Mining and Metal Industry: Alcan, Alcoa, Anglo American plc, AngloGold Limited, BHP Billiton, FreeportMcMoRan Copper \& Gold Inc., Mitsubishi Materials Corporation, Newmont Mining Corporation, Nippon Mining and Metals, Noranda Inc., Pasminco Limited, Placer Dome Inc., Rio Tinto plc, Sumitomo Metal Mining, Umicore, WMC Limited

Communication and Electronics Industrv: ABB, AT\&T, Electrolux, Ericsson, JohnsonDiversey, Lucent Technologies, Motorola, Nokia, Nortel Networks, Philips Electronics, Xerox

Others: Airbus, Boeing, Bombardier, EDF, Hydro-Québec, IKEA, Shell, United Technologies Corporation, Vattenfall

A benchmarking survey carried out in 1999 (Table 2) has shown that $92 \%$ of the 14 large corporations involved in motor vehicle industry were then carrying LCA and Design for Environment studies:

Table 2. LCA and DES in Selected Industries

\begin{tabular}{|c|c|c|c|c|c|c|c|c|c|}
\hline DE \&JCA & కัँ & 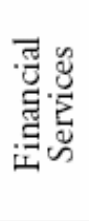 & 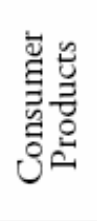 & 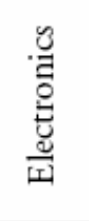 & 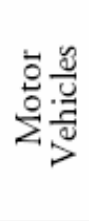 & 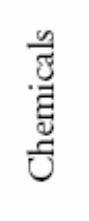 & 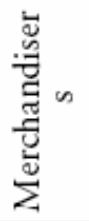 & 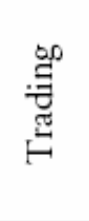 & 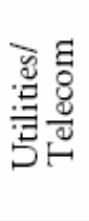 \\
\hline Gl00 Firms in Sector & 100 & 30 & 4 & $\overline{16}$ & $\overline{12}$ & 11 & 8 & 8 & $\overline{11}$ \\
\hline Reporting Firms & 48 & 4 & 4 & $\overline{16}$ & 11 & 8 & $\overline{0}$ & 1 & 4 \\
\hline Percent Reparting ' 99 & $48 \%$ & $13 \%$ & $100 \%$ & $100 \%$ & $92 \%$ & $73 \%$ & $0 \%$ & $13 \%$ & $36 \%$ \\
\hline Percent Repating ' 98 & $22 \%$ & $0 \%$ & $50 \%$ & $40 \%$ & $49 \%$ & $32 \%$ & $0 \%$ & $0 \%$ & $9 \%$ \\
\hline
\end{tabular}

Source: UNEP-SETAC, (2000)

\subsection{Limitations to LCA practices}

Many comments and critics have been posted on life cycle assessment methodology as standardized by ISO 10040. According to Bauer (2002):

- LCA is only one tool within the life cycle philosophy and the sustainable development way of thinking which is itself vaguely if not badly defined and at least subject of deep debates;

- LCA is targeting the selection of the "best" route between a departure point A and a destination B which is supposed to be better but is in reality full of uncertainties;

- LCA is not a universal inventory and assessment exercise which enables a multitude of decisions, each one being aligned to a specific decision context;

- LCA has no universal interpretation since much additional information might be expressed

Other comments that could be found in the literature:

- LCA data, when available, are challengeable in quality, reliability and Replicability as well as scientific validity; 
- LCA should be developed within a more general framework including social impacts as well as environmental.

\section{Case Studies}

\subsection{DaimlerChrysler}

\subsubsection{Strategy}

DaimlerChrysler has publicly committed itself to environmental protection. DC's Environmental Protection Guidelines include the following statements related to Design for Environment: “

- We strive to develop products which in their respective market segments are highly environmentally responsible. Our approach to environmentally acceptable design covers the entire product spectrum of the DaimlerChrysler Group, taking into account the product life cycle from design through disposal or recycling. Continuously improving the environmental performance of our products is one of our important goals. DaimlerChrysler is committed to the ongoing pursuit of this objective, especially in its research and development activities".

- "We plan all stages of manufacturing to provide optimal environmental protection. DaimlerChrysler sees itself as a leader in the ongoing development of environmentally responsible production technology which minimizes the burden on the environment. This includes proactive behavior to prevent or minimize the impact of accidents which may adversely affect the environment. Particular emphasis is given to the application and continuing development of technologies which save energy and water, and which are characterized by minimal emission and waste levels. This includes the development of effective environmental assessments, emission controls, reuse, and recycling strategies. DaimlerChrysler aims to achieve closed-loop material cycles. Our ultimate goal is waste-free production. DaimlerChrysler requires its suppliers and contractual partners to comply with all applicable laws and regulations and encourages them to pursue proactive environmentally responsible practices. Contractors working on DaimlerChrysler properties also must comply with the location's own standards and requirements."

Environmental protection is one of the fundamental corporate objectives of the DaimlerChrysler Group. In this context, environmental protection is an integral component of the corporate strategy, designed to ensure long-term value creation. DaimlerChrysler's goal of maximum product quality includes compliance with stringent environmental standards and careful treatment of the natural foundations of life. Accordingly, the approach to environmentally acceptable product design requires careful consideration of the entire product life cycle from design, production and use to disposal or recycling.

According to DaimlerChrysler, the environmentally compatible design of a vehicle should begin long before the first prototype takes shape on a CAD screen. In the DaimlerChrysler laboratories, environmental protection is built into the company's products from the outset, so to speak - in passenger cars, buses, vans and trucks alike. As the ecological impact of a vehicle is largely determined during the initial stages of its development, the earlier it is 
started, the more it could be achieved in terms of environmental protection, and the lower the cost and effort supported by the corporation will be (Figure 6):

Figure 6. Influence and Effects of Design for Environment (DfE) at DC

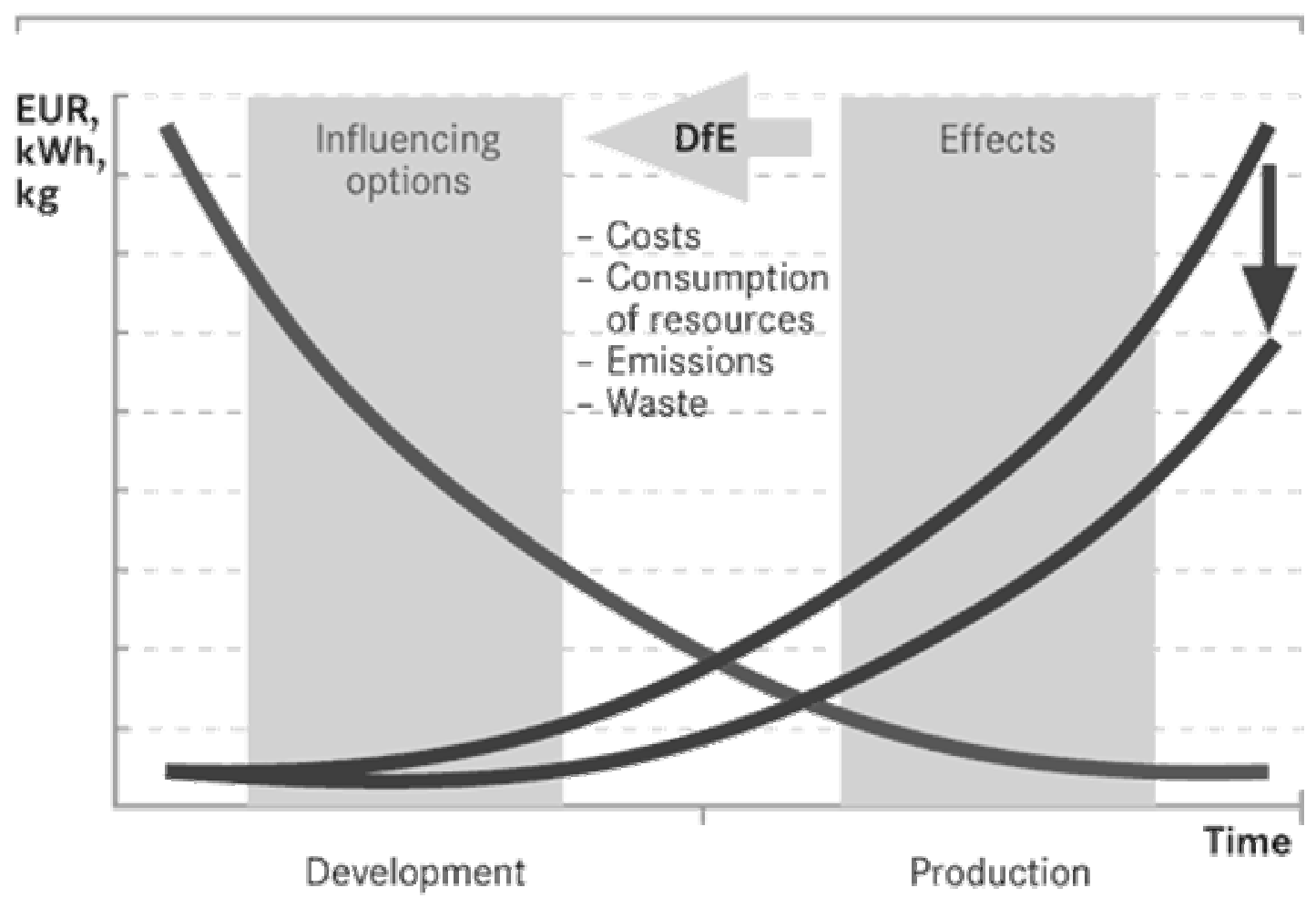

Even minor measures taken at the very early development stage would have significant effects at later stages and yield tangible reductions in environmental effects as well as in costs. By contrast, it is extremely difficult and costly to modify components at an advanced stage and even worse at production stage. An illuminating example is the extra cost impact of modifying the Mercedes Class A and the Smart after failure at the élan stability test some years ago.

This explains why a team of experts at the Design for Environment (DfE) department spend their time designing integral concepts for vehicles. Design for Environment deals with the selection of suitable raw materials and substances as well as with recycling-friendly design and production, enabling subsequent reuse or recycling of end-of-life vehicles and responsible disposal of replaced parts. Consequently, the DfE team includes experts from various areas: life cycle assessment; disassembly and recycling planning; materials and process engineering; design; and production. The team's activities are seamlessly integrated into each step of the development process in a "simultaneous engineering" approach.

Only an assessment of all environmental impacts across the vehicle's entire lifetime will reveal its overall energy consumption, waste generation and emission levels. Such an analysis covers all elements of the product life cycle, from raw materials extraction, through material manufacture, production and utilization, to disposal. As shown in Figure 7, a vehicle life cycle assessment (LCA) enables the Design for Environment experts to record and assess each component. The findings for the Mercedes E Class are the following: 
Figure 7. Environmental Impact on the lifecycle stages of a passenger car using the example of the Mercedes Benz E-Class

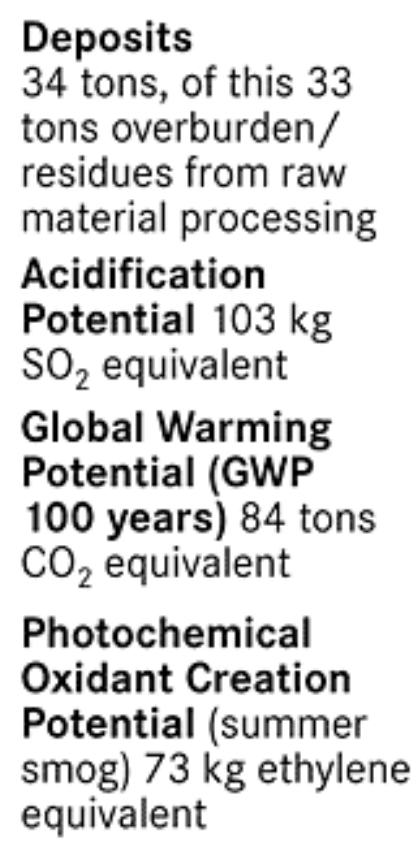

Deposits

34 tons, of this 33 tons overburden/ residues from raw material processing

Acidification

Potential $103 \mathrm{~kg}$

Global Warming

Potential (GWP

100 years) 84 tons

$\mathrm{CO}_{2}$ equivalent
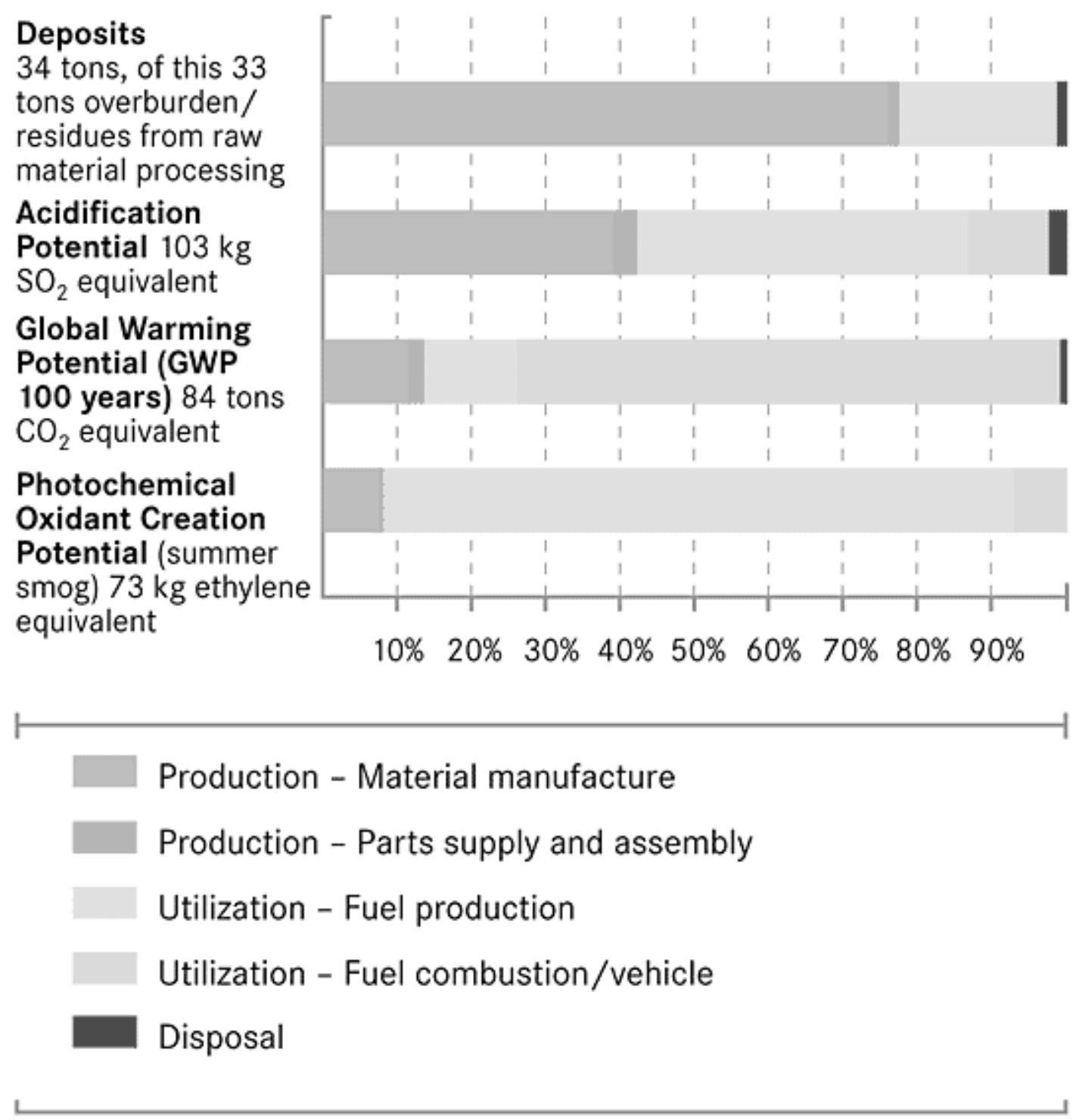

For materials, DaimlerChrysler claims that effective disassembly and recycling concepts as well as new technologies ensure fewer and fewer disposal of replaced parts from passenger cars and commercial vehicles. Using the MeRSy recycling management system, 30,000 metric tons of materials are now returned to the recyclable material loop each year in Germany, Austria, Switzerland and the Benelux countries alone. The system has been recently extended to Smart, Chrysler and Jeep vehicles.

\subsubsection{Environmental management and organization}

The Environmental Protection Guidelines have been approved by the Board of Management. They define the environmental policy of the DaimlerChrysler Group and describe the commitment to integrated environmental protection that addresses environmental impacts at their roots, assesses in advance the ecological implications of production processes and 
products, and takes these findings into account in corporate decision-making. Appropriate control and monitoring procedures and measures have been implemented.

Responsibility for environmental protection at DaimlerChrysler lies with the Group's Chief Environmental Officer, Prof. Herbert Kohler, who reports to the Board of Management on these matters at regular intervals, including a verifiable environmental report, published annually, which is documenting the Group's activities and achievements. His key tasks include ensuring that our environmental management system functions effectively. The efficiency of the system is regularly validated worldwide by external audits. $91 \%$ of DaimlerChrysler employees currently work at plants with certified environmental management systems. DaimlerChrysler is also increasingly focusing on environmental requirements in its suppliers.

At present, the main focus is on integrating the management systems for quality, environmental protection and industrial health and safety. This will enable DC to integrate environmental protection tasks more fully into the core functions and processes of the respective departments instead of dealing with them as separate processes. Implementation of the integrated concept was decided on in 2002, initially for the Mercedes-Benz passenger car plants in Germany and the USA. At the Chrysler Group plants, the environmental management system was integrated when it was introduced into the existing quality assurance system (Manufacturing Quality Assurance System, MQAS).

Ecological site audits are another important topic. These help DaimlerChrysler determine environmental risks, reduce them and raise all of our sites to a high environmental standard. To this end, a procedure has been developed that has already been successfully applied at numerous production and sales sites in recent years. In 2002, the group took a further step towards the goal of implementing it worldwide.

Other central elements of product- and production-related environmental protection at DaimlerChrysler are environmental education and communications. Unless the employees are aware of the environmental issues and committed to resolving them, DC cannot achieve the continuous improvements in environmental protection that has been planned.

Responsibility for the implementation of and adherence to environmental protection measures has been assigned to specific employees in all functional areas, from development and production to sales and service, and at all corporate staffs.

The Environmental Protection Guidelines are binding for all the Group's employees and at all corporate locations. Accordingly, the Group supports and encourages all employees to put environmental protection into practice at the workplace at his or her own initiative. Measures implemented at the various corporate locations are regularly assessed and subject to a process of continual improvement. In order to comply with its self-imposed environmental protection standards, the DaimlerChrysler Group draws up its own environmental goals. The ecological programs required to meet these goals are monitored through a comprehensive auditing process aimed at measuring compliance with procedures and regulations, and when necessary, corrective actions are taken to improve performance.

An extensive catalogue of environmental targets defines the environmental protection roadmap at DaimlerChrysler. These targets are up-dated annually and a review of the extent to which they have been achieved is carried out. 


\subsubsection{Data Collection}

A systematic compilation of key environmental data from the DaimlerChrysler German plants in 1992. In 1997 and 1998, data acquisition was gradually extended to include production plants outside Germany in which the DaimlerChrysler Group is the majority shareholder.

The data for resources (input) and waste and emissions (output) is restricted to DaimlerChrysler's own locations. The specific values arrived at by these means are approximate guidelines, because they take no account of different depths of vertical manufacturing, the frequently substantial differences in the products built by the various divisions or the peculiarities of the different integrated production networks.

\subsubsection{Other Studies}

Sorensen (2003) has studied PEM fuel cell cars of which the DaimlerChrysler f-cell (35MPa $\mathrm{H} 2$ fuel PEMFC/electric motor) comparing with a Toyota Camry powered by an Otto engine and a VW Lupo powered by a common rail diesel engine.

\subsubsection{Comments}

DaimlerChrysler is basically following the model developed by the VDA which is clearly considered so far as the standard for products designed for the European market.

It is important to pinpoint that even if they are very well identified and occasionally involved in international scientific conferences, DaimlerChrysler experts for life cycle assessment still argue that information about life cycle assessment practices are very confidential since they might enlighten the corporation product development strategy and the methods in place, then opening too much to competitors or potential critical views by environmental organizations. It is indeed particularly true in Germany and by extension in Europe with the rise of environmental concerns with customers and governments, including in emerging countries such as China where the corporation is industrially present.

\subsection{Ford Motor}

Ford is currently using life cycle assessment and life cycle design for most of its new vehicles (passenger cars as well as trucks), for its research vehicles (hybrid, electric, etc.) and for most of its mechanical components. Ford Europe started to use life cycle assessment for the first time in 1992. Early developments were made in the United States. So far more than 100 life cycle assessment studies have been carried since then.

\subsubsection{European Subsidiaries}

\section{Jaguar}

Ford's subsidiary Jaguar has used life cycle assessment for the development of the new XType Jaguar. In 1998, Jaguar was assessed by the Vehicle Certification Agency (VCA). This resulted in Jaguar Cars being awarded certification to ISO 14001, the International Standards Organisation's accreditation for environmental management systems. 
Jaguar's commitment to the environment starts at the top with Chairman Nick Scheele who stated that environmental performance as a strategic issue. Jaguar's first formal recognition that environmental issues were a priority came in 1992 with the formation of an Environmental Strategy Committee, set up primarily to look at ways of making its cars more 'eco-friendly'. The Committee's ideas were rapidly translated into actions as the company introduced a series of component and materials changes with long-term environmental benefits.

Having successfully raised the environmental credentials of the products themselves, Jaguar's environmental team also turned its focus to the company's processes. Dr. Geraint Williams spearheads Jaguar's ISO 14001 task force:

According to Joe Greenwell, Chairman and Chief Executive Officer, Jaguar's Sustainable Development Policy details its long-term aims and commitments. This is supported by a strategy framework and a series of Key Sustainable Development Goals, which set direction and clear targets for the company. Jaguar is currently developing a 10-year vision to guide its sustainable development route map for the future and to ensure that this is satisfying their stakeholders' requirements.

An essential element to the success of Jaguar's policies and strategies is ensuring their integration into the decision-making process. Sustainable development has been incorporated within Jaguar's high-level Business Plan Scorecard. These requirements translate down to all the functions and progress is monitored regularly by senior management.

\section{Volvo}

The Volvo branch, whose brand image is very much linked to safety and ecology, is indeed very much engaged in life cycle assessment.

Before being integrated within Ford Group, Volvo has developed in 1990 a specific approach named Environmental Priority Assessment (EPS) (Figure 8) as part of its strategic choice made official in 1989 towards clean and safe vehicles.

Figure 8. Volvo's EPS Model

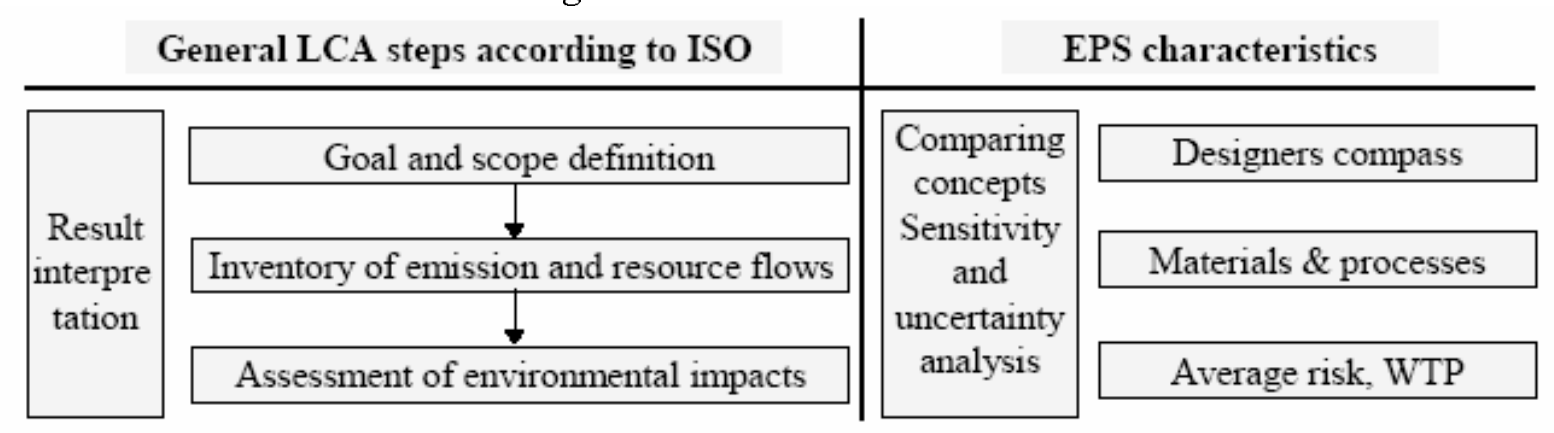

Source: Steen, Wendel, 1998.

The customer general environmental view is evaluated by means of the so-called willingness to pay for changes (WTP) for emissions and WTP for alternative renewable methods for raw material resources. EPS has been used for the Volvo S80-model.

Since then Volvo has developed SPINE (Sustainable Product Information Network for the Environment), a database for LCA with activity as main concept, e.g. raw material extraction, 
assembly, use of a product, etc., with inputs and outputs described by flows connecting activities. Software handles the data and the structure, i.e. the whole modelling of the set of activities.

Since 2000, the process of environmental decisions within the product Development Department is the following (Figure 9):

Figure 9. Volvo Decision Process

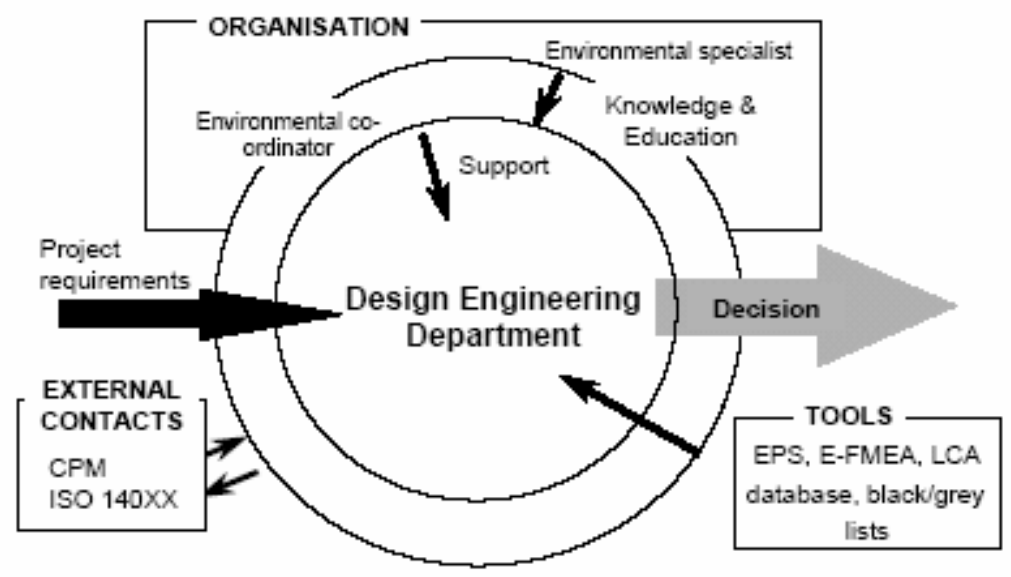

Volvo is making use of E-FMEA, a group method for identifying important environmental aspects early in the product development phase. During meetings, a group of engineers combines skills and know-how and experience to identify every conceivable environmental aspect which a product or a component may have during its lifetime.

\subsubsection{Practical Applications of LCA at Ford Motor}

\section{Full vehicle LCA}

A very limited number of life cycle assessment studies have been published concerning Ford vehicles of the current model range.

\section{Innovations and Vehicles for the Future}

The University of Carnegie-Mellon is working closely with Ford. The University of CarnegieMellon (2003) suggests there are a variety of methods to be used for life-cycle assessment. They suggest the following matrix (Figure 10) crossing life cycle stages with life-cycle impacts: 
Figure 10. Carnegie Mellon LCA Matrix

\begin{tabular}{|l|l|l|l|l|l|}
\hline $\begin{array}{l}\text { Inventory } \\
\text { Catezory/Life } \\
\text { Stage }\end{array}$ & Prernanufacture & $\begin{array}{c}\text { Product } \\
\text { manufacture }\end{array}$ & $\begin{array}{c}\text { Product } \\
\text { delivery }\end{array}$ & Product use & $\begin{array}{c}\text { Refurbishmeat, } \\
\text { recycling, } \\
\text { disposal }\end{array}$ \\
\hline $\begin{array}{l}\text { Materials } \\
\text { choice }\end{array}$ & & & & & \\
\hline Energs use & & & & & \\
\hline Solid residues & & & & & \\
\hline Liquid residues & & & & & \\
\hline $\begin{array}{l}\text { Gaseous } \\
\text { residues }\end{array}$ & & & & & \\
\hline
\end{tabular}

The University of Carnegie-Mellon also links LCA and input-output analysis. The model has been made available on-line for teaching purposes (www.eiolca.net). They have applied the model to the Ford's ECOSTAR, a battery-electric vehicle (BEV), the Honda's Insight, a hybrid electric vehicle (HEV) and GM's EV1, another BEV. The model is given as an attachment to the lessons.

Volvo used its EPS methodology for evaluating the environmental impact of its ECT Environmental Concept Truck (ECT) prototype, a hybrid vehicle using a gas turbine for charging nickel-metal hybrid battery pack (Karlsson, Wendel, 1998).

\section{Components}

For many components, Ford is teaming with the Centre for Sustainable Systems from the University of Michigan, Ann Arbor:

In 1999, the partnership analysed the lower plenum of the air intake manifold for use with the 5.3 L F-250 truck engine. The life cycle design (LCD) methodology has been applied to three alternatives: a sand cast aluminium, a lost core molded nylon composite and a vibration welded nylon composite.

The methodology is well known

1. Chart the process flow from production of raw materials to shredding, recycling and waste disposal, including manufacturing and use;

2. Collect data for all stages including performance analysis and cost analysis;

3. Evaluate environmental inventory;

4. Evaluate costs;

5. Assess internal and external environmental requirements;

6. Evaluate weaknesses and bias in data collection;

7. Make Decision.

It is important to note (see Table 3) than Ford-CSS are using both internal and external requirements for environment protection in their decision making process: 
Table 3. Internal and External Environmental Requirements for Ford Motor

\begin{tabular}{|c|c|c|}
\hline & Internal & External \\
\hline Energy & $\begin{array}{ll}\text { - } & \text { Corporate citizenship } \\
\text { - } & \text { Minimize facility energy (directive } \\
& \text { D101†: energy planning and control) } \\
\text { - } & \text { Meet platform fuel economy targets }\end{array}$ & - $\mathrm{CAFE}$ \\
\hline Materials & 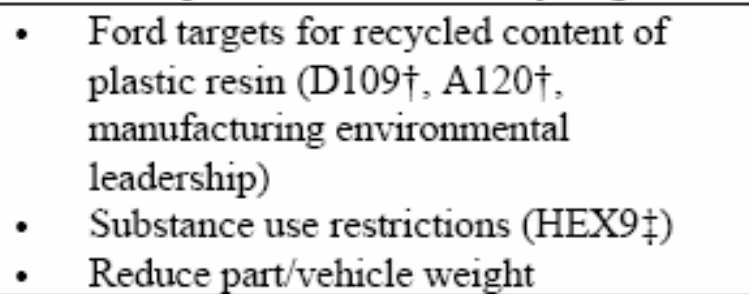 & $\begin{array}{l}\text { - Reduce materials used, } \\
\text { increase materials } \\
\text { recycled }\end{array}$ \\
\hline Waste & $\begin{array}{ll}\text { - } & \text { Protect health and environment (policy } \\
& \text { letter } 17 \text { ) } \\
\text { - } & \text { Recyclability targets (directive F-111 }) \\
\text { - } & \text { Reduce manufacturing waste (A-120 })\end{array}$ & $\begin{array}{l}\text { - Voluntary initiatives to } \\
\text { reduce greenhouse } \\
\text { emissions }\end{array}$ \\
\hline
\end{tabular}

$\dagger$ Ford directives and guidelines

$\ddagger$ Ford Engineering Specifications for Materials

Source: Spitzley, Keoleian, (1999),

Then, using the manifold example, the decision might be made using several criteria:

Table 4. Ford's Criteria for the Truck Air Manifold

\begin{tabular}{|c|c|}
\hline Criteria & Manifold Selection \\
\hline $\begin{array}{l}\text { - Manifold with the lowest total life cycle } \\
\text { energy consumption: }\end{array}$ & Vibration welded composite (1,18 MJ) \\
\hline - Manifold with the highest recycled content: & Sand cast aluminum (100\%) \\
\hline $\begin{array}{l}\text { Manifold with the highest end-of-life } \\
\text { recyclability }^{\dagger} \text { : }\end{array}$ & Sand cast aluminum (100\%) \\
\hline $\begin{array}{l}\text { - Manifold with the lowest total life cycle } \\
\text { solid waste production: }\end{array}$ & Vibration welded composite $(4.45 \mathrm{~kg})$ \\
\hline - Manifold with the lowest life cycle cost: & Vibration welded composite $(\$ 8.10+x)$ \\
\hline
\end{tabular}

Sullivan (2001), from Ford Research Laboratory in Dearborn (USA), is advocating life cycle assessment and the development of sustainability or eco-efficiency metrics for vehicles, i.e. measures of resources and materials consumed per unit output of products couples with measures of environmental performance as well as social-equity of such products.

According to Louis \& Wendel (2001), the Volvo LCA-EPS has been and is still extensively used for components when different alternatives are available such as the choice between materials, e.g. the tailgate panel structure $\left(5^{\text {th }}\right.$ door $)$. As indicated in Figure 11 , the methodology is the following ${ }^{2}$ :

\footnotetext{
${ }^{2}$ ELU is the equivalent of Euro.
} 
Figure 11. The EPS Methodology

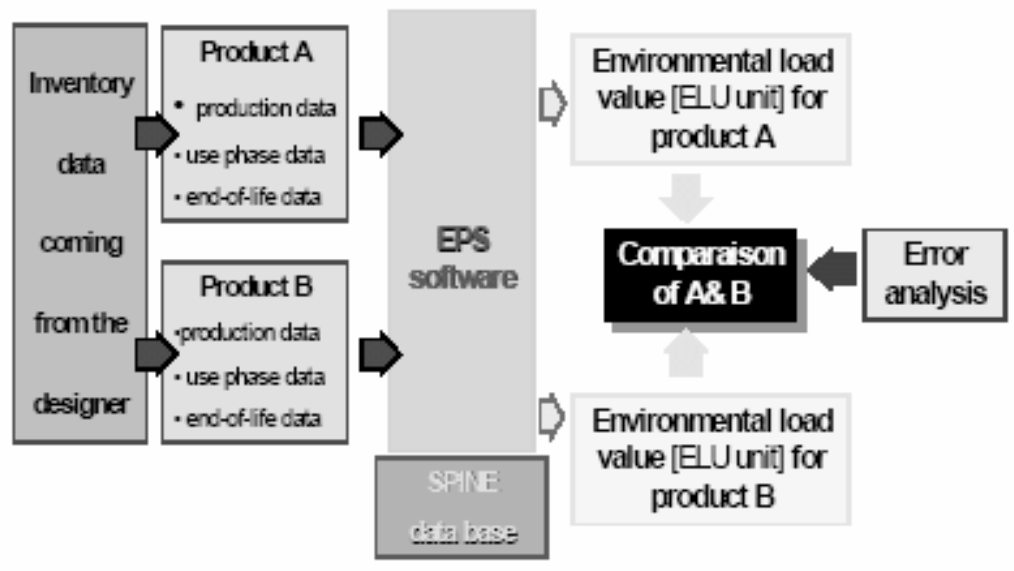

According to a Technical Specialist Vehicle Recycling at Ford Werke AG, Vehicle Recycling, Ford is a major partner in two research projects, the first one dealing with life cycle assessment methodology, the second with bio-fuels and materials:

- Enhancing the Application Efficiency of Life Cycle Assessments for industrial applications with Motorola and Alcan. This research project focuses on the implementation of LCA in industry and aims to enhance the application efficiency by:

1. Improving the LCA methodology in regards to focusing on the most significant processes, specifically concentrating on the life cycle inventory (LCI), and

2. The use of life cycle inventory data for life cycle costing assessments.

- Review of Life Cycle Assessment studies for Biofuels, Biomolecules and Biomaterials with funding by Environmental and Energy Management Agency France (ADEME) and in partnership with Bonnard \& Gardel with a case study of a Front Sub-frame System;

\subsubsection{Comments}

Ford emphasises two reasons for engaging in LCA: this has been a deliberate choice at board level which did proclaim that Ford cars should have the minimum environmental impact and the pressure from the European institutions is playing a key role in such option. It is interesting to note that Ford is not considering economic factors such as financial and tax incentives and marketing to customers as influential so far. For Ford, environment issues are not a selling weapon in Europe since they do not yet appeal to customers.

Ford is extensively using ISO 14000 standards since these norms have been designed, discussed and adopted by all ISO members states and organisations. But Ford LCA experts have also elaborated complementary assessment such as stakeholders' needs and priorities. Life cycle assessment is a key strategic tool to foresee and understand the futures issues at stake during the life cycle as a whole. It is also a benchmarking exercise allowing comparison with competition and with older models and previous technological choices. Ford has developed its own internal life cycle assessment software tool which is used for most life cycle assessment studies that are carried out and often published since the head of the team is 
a member of the European automotive life cycle assessment group and very active in the life cycle assessment community.

Life assessment studies are carried out at three different levels:

- Environmental department;

- Product development, in particular people in charge of vehicle integration;

- Research when future vehicle models are concerned.

Each life cycle assessment is carried out by a multi-functional team composed with representatives of three departments or functions: environment, research and vehicle integration.

\subsection{Volkswagen Group}

Similarly to its main European competitors, Volkswagen Group is also making an extensive use of life cycle assessment for its new models and new components. The advertising of ISO 14000 labels for the company's flagship, the Golf, is indeed very important, in particular in Germany where the environmentalists are quite influential. Figure 12 is presenting the VW process.

Figure 12. VW LCA Process

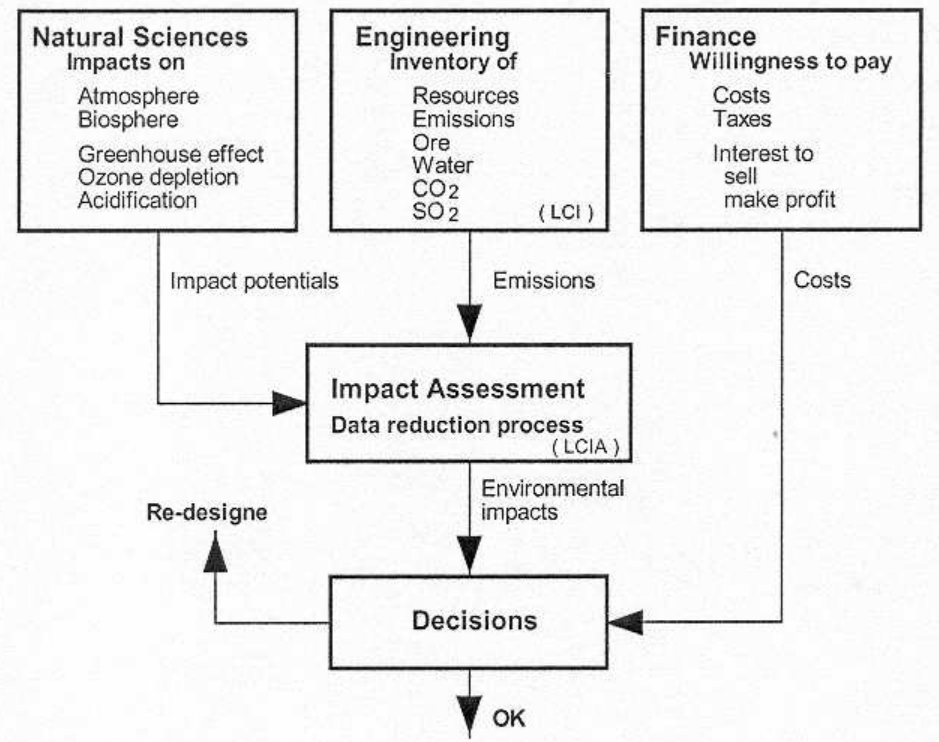

Data sources and flows in a LCA. The main effort consists in the data acquisition. The impact assessment is an easy mathematical step.

As pointed out by Schweimer \& Levin (2001), from Volkswagen AG \& the Center of Environmental Systems Research of the University of Kassel, Volkswagen initiated environmental inventories ${ }^{3}$ for whole vehicles in 1992. Whole vehicle LCA reports are publicly published and incidentally made easily available on Volkswagen web site. They strictly follow the ISO 14040/41 international standards. Volkswagen's LCA reports deal with

\footnotetext{
${ }^{3}$ In German, sachbilanz.
} 
all stages of the life cycle, including assessing the environmental impacts in its suppliers' plants.

It is important to pinpoint that Volkswagen Group claims that LCA can only be carried out with the support of independent experts when delivering the ISO 14040-41 standards.

A good example of recent assessment exercise is the Golf A4 (Figure 13 \& Table 5) life cycle assessment (Schweimer \& Levin, 2001), where comparisons could be made on several generations of the same model:

\section{Figure 13. Golf 4 LCA Model}

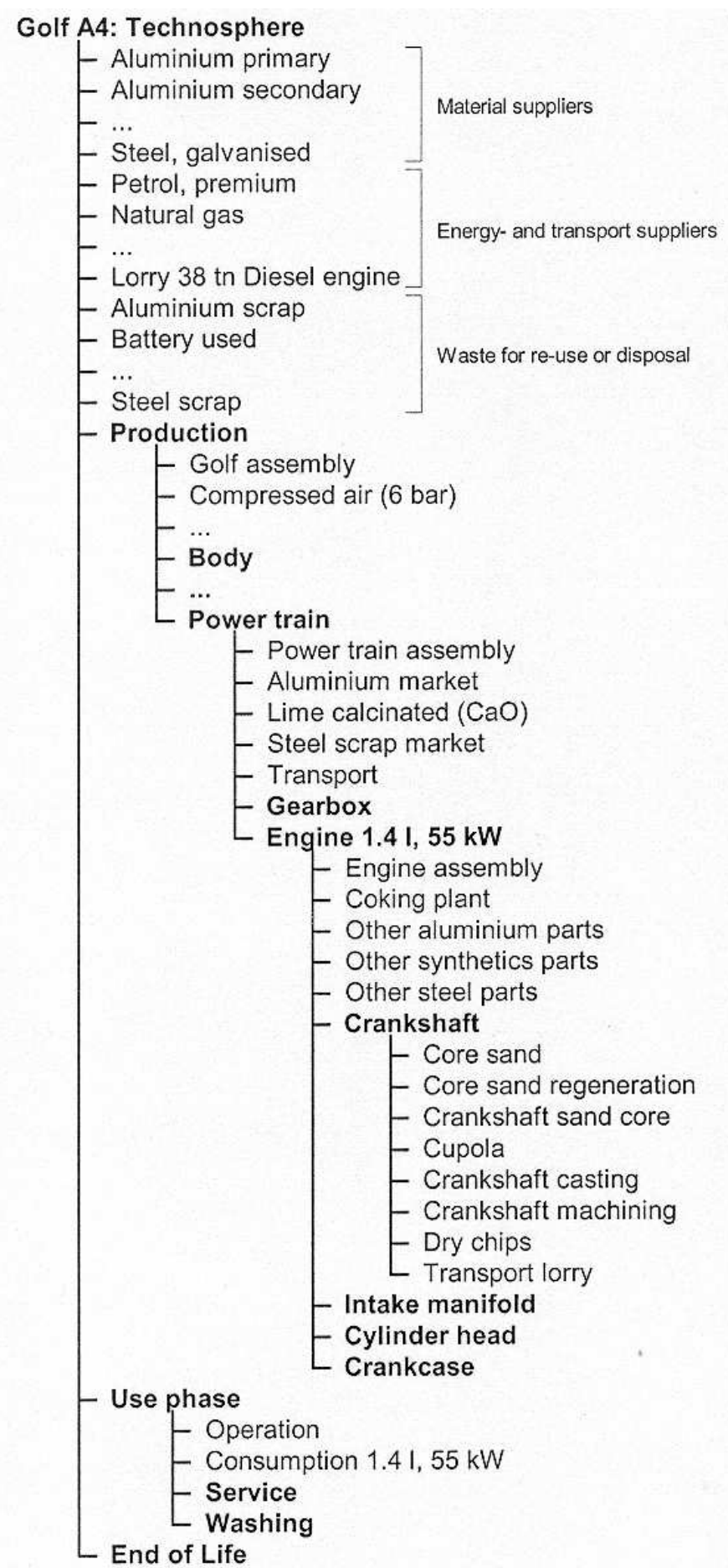


Table 5. Comparing various Golf and Lupo LCA results

\begin{tabular}{|l|c|c|c|c|l|}
\hline Material/ Energy & Golf A4 & Golf A4 & Golf A3 & Lupo 3L & Primary Reason / Cause (A4 / A3) \\
\hline & diesel & petrol & petrol & diesel & \\
\hline Curb weight & $1181 \mathrm{~kg}$ & $1059 \mathrm{~kg}$ & $\begin{array}{c}1025 \mathrm{~kg} \\
800\end{array}$ & Larger vehicle \\
\hline $\begin{array}{l}\text { Primary energy } \\
\text { (prod.'n/use/end of life) }\end{array}$ & $\begin{array}{c}113 \\
\mathrm{MWh}\end{array}$ & $\begin{array}{c}124 \\
\mathrm{MWh}\end{array}$ & $\begin{array}{c}150 \\
\mathrm{MWh}\end{array}$ & $\begin{array}{c}70 \\
\mathrm{MWh}\end{array}$ & $\begin{array}{l}\text { Lower consumption: } 4.9 \text { and } 6.5 \\
\text { compared with } 8.1 \mathrm{I} / 100 \mathrm{~km}\end{array}$ \\
\hline Steel & $722 \mathrm{~kg}$ & $634 \mathrm{~kg}$ & $650 \mathrm{~kg}$ & $410 \mathrm{~kg}$ & Heavier vehicle \\
\hline Synthetics, rubber & $249 \mathrm{~kg}$ & $228 \mathrm{~kg}$ & $170 \mathrm{~kg}$ & $130 \mathrm{~kg}$ & \\
\hline Aluminium & $50 \mathrm{~kg}$ & $52 \mathrm{~kg}$ & $30 \mathrm{~kg}$ & $130 \mathrm{~kg}$ & Light-weight design of Lupo 3L TDI \\
\hline $\mathrm{CO}_{2}$ emissions & $27 \mathrm{tn}$ & $30 \mathrm{tn}$ & $36 \mathrm{tn}$ & $16 \mathrm{tn}$ & Lower consumption \\
\hline $\mathrm{HC}$ emissions & $60 \mathrm{~kg}$ & $108 \mathrm{~kg}$ & $160 \mathrm{~kg}$ & $40 \mathrm{~kg}$ & Low-level refilling losses for diesel \\
\hline $\mathrm{SO}_{2}$ emissions & $29 \mathrm{~kg}$ & $30 \mathrm{~kg}$ & $34 \mathrm{~kg}$ & $20 \mathrm{~kg}$ & Lower consumption \\
\hline NOx emissions & $77 \mathrm{~kg}$ & $24 \mathrm{~kg}$ & $26 \mathrm{~kg}$ & $51 \mathrm{~kg}$ & No NOx cat for diesel \\
\hline $\begin{array}{l}\text { Dust/particulate matter } \\
\text { emissions }\end{array}$ & $15 \mathrm{~kg}$ & $10 \mathrm{~kg}$ & $8 \mathrm{~kg}$. & $10 \mathrm{~kg}$ & $\begin{array}{l}5 / 0,4 / 2 / 3 \mathrm{~kg} \text { of which are the result } \\
\text { of engine emissions }\end{array}$ \\
\hline
\end{tabular}

Volkswagen is one of the four OEMs to be involved in the FUERO (www. fuero.org) project together with Renault, Peugeot-Citroën and Volvo about fuel cells components with a 4.5 million euro budget. The whole work package 8 is dedicated to the life cycle assessment.

Nicolay (2000) compared the LCA results of a Seat Ibiza TDI with Mitsubishi $2000 \mathrm{~cm}^{3}$ petrol, an electric Peugeot 106 and a Toyota Prius.

Like DaimlerChrysler, VW LCA experts still consider information about organizational issues and methodologies for LCA as strictly confidential.

\section{Conclusion(s)}

The survey leads to several interesting conclusions:

1. The main reason for European OEM for engaging in life cycle assessment is linked to political pressures from different levels. Indeed the European institutions are by far the strongest and most influential lobby. Environmental organizations play a secondary role everywhere but in Germany: therefore German vehicle manufacturers have to be active and communicate on such issues.

2. Economic factors have no real influence. The commercial or marketing factors have a very limited impact: customers are not yet ready to pay a visible premium for a "clean" and fully recyclable car. Environmental issues are a weak selling argument in Europe

3. On the other hand, strategic factors might play a crucial role. Engaging in life cycle assessment is a board-level decision and the professional organizations at national level, VDO in Germany and ACEA at European level, are actively involved in disseminating methods and best practices in life cycle assessment. 
4. As far as method is concerned European OEMs are applying ISO 14000 standards, but they have also elaborated complementary assessment techniques in order to integrate other industry-specific and often confidential information. Therefore, most of them are reluctant to publish full reports. They rather prepare a specific and short document which is made public some time after the commercialization of a new vehicle.

5. European OEMs use the following software tools: GaBi, which is by far the most widely used in the European automobile industry, SimaPro and Umberto. Some interfaces exist between LCA and broader management tools, but a full integration is probably not planned and may be also not the right direction.

6. All OEMs are using LCA for vehicle (new models), platforms and components as well as for assessing innovative technologies and vehicles of the future.

7. By far, the most important problem that European OEMs are facing with LCA is the scientific validity of the measurement technique. Then the availability and quality of data are considered as challengeable.

Table 6. Main problems with LCA data reliability

\begin{tabular}{|l|l|}
\hline 1 & They consider that some assessment measures are not scientifically valid \\
\hline 2 & Some data are simply not available \\
\hline 3 & Poor quality of data \\
\hline 4 & Comparability over time is not feasible \\
\hline 5 & External suppliers of data do or could not reply \\
\hline 5 & Methodological bottlenecks: new methods and tools should be developed \\
\hline
\end{tabular}

8. Generally speaking, LCA studies are carried out at corporate division level. But sometimes they are also embedded in line management. Most LCA assessment experts are part of a Design for Environment and/or recycling department. Such organization is explicitly multi-functional.

It is important to keep in mind that life cycle assessment was developed thirty years ago (Gauthier, 2004), in order to respond to the specific needs of companies seeking to respect the environment while developing and improving their products. It is not more than a decisionmaking tool, the use of which being governed by an international standards 14040, 14041, 14042 and 14043. As pointed out by Contadini \& Moore (2003), life cycle assessment involves some subjectivity and uncertainty, especially with new technologies and future scenarios.

There is still research to be carried out in the near future about practices within other OEMs, in particular in the United States, Korea and Japan. A survey of suppliers might provide very interesting information about the dissemination of LCA practices within the automotive value chain, i.e. the automotive system as defined by de Banville, Chanaron (1991). And obviously, practices in this specific sector must be benchmarked with best practices in other industries. It would also be very interesting to compare practices for traditional technologies and for emerging technologies such as hybrid and fuel-cell vehicles. 


\section{References}

Bauer, C., (2002), Report on Policy Making, Non-Ferrous Metals and Life Cycle Studies, Non-Ferrous Metals Consultative Forum on Sustainable Development, Aachen University.

Carnegie-Mellon University (2003), Streamlined Life Cycle Assessment and Input-Output Analyses.

Chanaron, J.J., De Banville, E., (1991), Vers un système automobile européen, Paris, Economica.

Contadini, J.F., Moore, R.M., (2003), Results of a Life Cycle Assessment Using Uncertainty Analysis of Fuel Cell Vehicles Within the South Coast Air Basin of California in 2010, University of California, Davis, LCA Case Studies, International Journal of Life Cycle Assessment (IJLCA), pp. 1-15.

Contadini, J.F., Moore, R.M., Mokhtarian, (2002), Life Cycle Assessment of Fuel Cell Vehicles, A Methodology Example of Input Data Treatment for Future Technologies, LCA Methodology, International Journal of Life Cycle Assessment (IJLCA), $\mathrm{n}^{\circ}$ 7, pp. 1-12.

Dhingra, R., Overly, J.G., Davis, G.A., Das, S., Hadley, S., Tonn, B., (2000), A life-Cycle-Based Environmental Evaluation: Materials in New Generation vehicles, SAE Technical Paper Series, 2000-01-0585, presented at SAE 2000 World Congress, Detroit, March 6-9.

Finkbeiner, M., Krinke, S., Oschmann, D., Saeglitz, T., Schäper, S., Schmidt, W., Schnell, R., (2002), Data Collection Format for Life Cycle Assessment of the German Association of the Automotive Industry (VDA)

Gauthier, C., (2004), Sustainable Development: a New Life Cycle Assessment, Grenoble Ecole de Management.

IKP, (2003), GaBi, a Life Cycle Assessment Software, Department of Life Cycle Engineering, The University of Stuttgart, Stuttgart.

IVL, (2000), LCA Software Survey, Stockholm.

Karlsson, R., Wendel, A., (1998), EPS as a Life Cycle oriented System Assessment Tool to Facilitate Industrial Learning about Relations to the Environment, AB Volvo \& Chalmers University of technology.

Keoleian, G.A., (2001), Application of LCA in Life Cycle design: Two Demonstration Projects, Center for Sustainable Systems, University of Michigan, Ann Arbor.

Louis, S., Wendel, A., (1998), Life Cycle Assessment \& Design, Experience from Volvo Car Corporation, Society of Automotive Engineers.

Louis, S., Wendel, A., (2001), Integration of Environment within the Product Process Development at Volvo Car Corporation, Volvo Car Corporation.

MacLean, H. L., Lave, L. B., (1998), A Life Cycle Model of an Automobile, Environmental Science \& Technology, No. 32(3), pp. 322A-330A.

MacLean, H. L., Lave, L. B., (1999), Life Cycle Models of Conventional and Alternative-Fueled Automobiles, Carnegie Mellon University, Green Design Initiative.

Nicolay, S., (2000), A Simplified LCA for Automobile Sector, Comparison of ICE (petrol and diesel), electric and hybrid vehicles, University of Liège, $\boldsymbol{8}^{\text {th }}$ LCA Case Studies Symposium, SETAC-Europe.

Quella, F., Schmidt, W.P., (2003), Integrating Environmental Aspects into Product design and Development, Part 1: The new ISO TR 14062, International Journal of Life Cycle Assessment, ${ }^{\circ} 8$ (2), pp. 113-114.

Quella, F., Schmidt, W.P., (2003), Integrating Environmental Aspects into Product design and Development, The new ISO TR 14062 - Part 2: Contents and Practical Solutions, Gate to EHS: Life Cycle Management Design for Environment, March $17^{\text {th }}$, pp. 1-7.

Rebitzer, G., Hunkeler, D., (2003), Life Cycle Costing in LCM: Ambitions, Opportunities, and Limitations. Discussing a Framework, International Journal of Life Cycle Assessment, $\mathrm{N}^{\circ}$ 8(5), pp. 253-256. 
Rebitzer, G., Schmidt, W.P., (2003), Design for Environment in the Automotive Sector with the Materials Selection Tool euroMat, Gate to EHS: Life Cycle Management - Design for Environment, March 17 ${ }^{\text {th }}$, pp. 1-4.

Riley, C., Sheehan, J., (2000), Bio-ethanol from Corn Stover: A Life Cycle Assessment, National Renewable Energy Laboratory, U.S. Department of Energy.

Schweimer, G.W., Levin, M., (2001), Life Cycle Inventory for the Golf A4, Volkswagen AG \& Center of Environmental Systems Research, University of Kassel.

Schweimer, G.W., Schuckert, M., (1996), Life Cycle Inventory for a Golf, Volkswagen AG.

Schweimer, G.W., (1998), Life Cycle Inventory of the 3 litre Lupo, Volkswagen AG.

Schweimer, G.W., (2000), Life Cycle Inventory of the SEAT Ibiza, Volkswagen AG.

Shaw, J., Heenan, W., Smith, V., (2003), USLAB-AVC (Advanced Vehicle Concepts) - A Solution for Today Engineering, Life Cycle Inventory and Costs Analyses.

Sorensen, B., (2003), Total Life Cycle Assessment of PEM Fuel Cell Car, Roskilde University, Denmark.

Spitzley, D.V., Keoleian, G.A., (1999), Life Cycle Design of Air Intake Manifolds, Center for Sustainable Systems, University of Michigan and Ford Motor Company, EPA/600/R-01/059.

Spitzley, D.V., Grande, D.E., Gruhl, T., Keoleian, G.A., Bean, J.C., (2004), Automotive Life Cycle Economics and Replacement Intervals, Center for Sustainable Systems, University of Michigan, Ann Arbor, $7^{\text {th }}$ January, No.CSS04-01.

Steen, B., Wendel, A., (1997), Experiences from introducing LCA and the EPS system in industrial product development, Volvo Car Corporation \& Chalmers University of technology.

Sullivan, J.L., (2001), Sustainability metrics for vehicles, Pure and Applied Chemistry, No. 73, pp. 1273-1276.

Sullivan, J. L., Williams, R., Yester, S. Chubbs, S., Hentches, S., Pomper S. (2001), ,Life Cycle Inventory Analysis of a Generic Vehicle; Overview of Results, SAE Paper \#982160 and SAE Transactions, 1999

Sullivan, J. L., Cobas Flores, E., (2001), Full Vehicle LCAs: A Review, The 2001 Environmental Sustainability Conference, Graz, Austria, SAE Paper \#2001-01-3725.

UNEP-SETAC, (2000), International Life Cycle Partnership, Life Cycle Initiative, A Brochure, Paris.

Winthrop, M. Jr, (1994), Life Cycle Assessment, West Virginia University, Extension Service, WLG 306. 